\title{
Simultaneous bilateral triquetral fractures, acquired in two separate accidents within $9 \mathrm{~h}$
}

\author{
Vincent P Sluiters, Ewan D Ritchie, Willem-Maarten Bosman
}

Department of Surgery, Rijnland Ziekenhuis, Leiderdorp, The Netherlands

\section{Correspondence to} Dr Ewan D Ritchie, e.ritchie@rijnland.n

Accepted 4 April 2014

\section{CrossMark}

To cite: Sluiters VP, Ritchie ED, Bosman W-M. BMJ Case Rep Published online: [please include Day Month Year] doi:10.1136/ bcr-2014-203612

\section{DESCRIPTION}

A 49-year-old man presented to the emergency department at 10:00 in the morning with a painful right hand after falling off his bicycle. Physical examination showed pain and swelling over the dorsum of the hand. Anteroposterior and lateral radiographs showed a triquetral avulsion fracture with minimal dislocation (figure 1). The injury was treated with a dorsal forearm splint.

The same evening, at 19:00, the patient returned to the hospital after falling off his bicycle again. This time, his left hand and wrist were painful. Radiographs showed a triquetral avulsion fracture, almost identical to the one on the right side (figure 2). This fracture was also treated with a dorsal forearm splint. Both the fractures recovered without any problems within 2 months after the accidents.

After fractures of the os scaphoid, fractures of the os triquetrum are the second most common fracture of the carpal row. However, they represent only $3-5 \%$ of all carpal fractures. ${ }^{1}$ The mechanism of injury is often a fall on the (hyper)extended and ulnar deviated hand. Radiographic findings suggest avulsion of the fragment by some kind of tendinous insertion, however this is not possible as there is no insertion on this particular carpal bone. ${ }^{2}$ The fracture is actually caused by the hamate bone or in some cases the ulnar styloid process acting as a

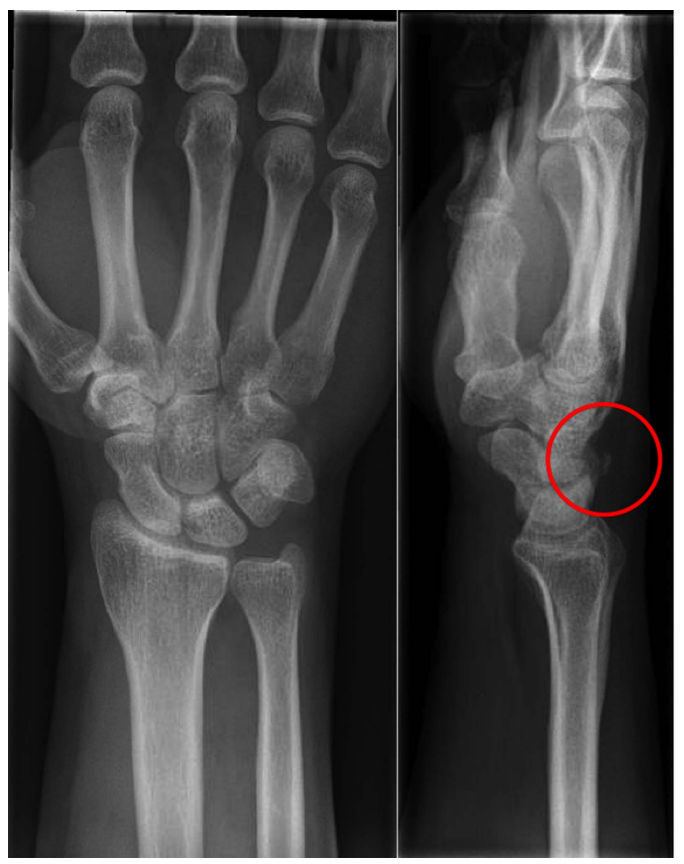

Figure 1 Anteroposterior and lateral radiographs of the right wrist showing a chip fracture of the os triqeutrum (red circle).

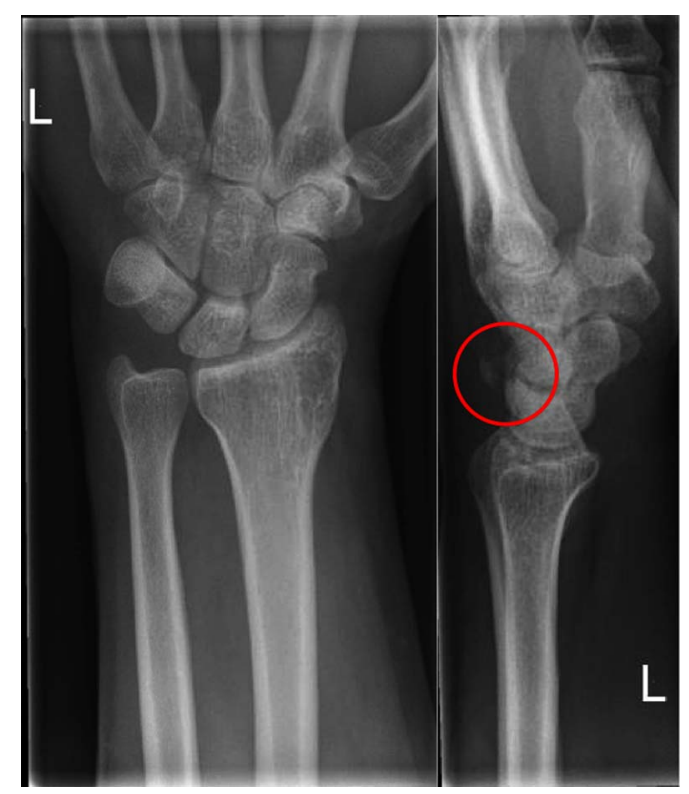

Figure 2 Anteroposterior and lateral radiographs of the left wrist showing a chip fracture of the os triqeutrum (red circle), images acquired $9 \mathrm{~h}$ after figure 1.

chisel chipping away a small dorsal fragment of the os triquetrum. ${ }^{3}$

The affected wrist is immobilised by a dorsal forearm splint for 3-6 weeks. Avascular necrosis or non-union is extremely rare because of the excellent vascularisation of the bone and there is no indication for surgical intervention for avulsion fractures. $^{3}$

Current case shows an unfortunate occurrence of a bilateral triquetral fracture in one patient. The

\section{Learning points}

- Triquetral fractures are the second most common carpal fracture.

- The mechanism of injury is often a fall with the hand in hyperextension and ulnar deviation.

- Triquetral fractures are no true avulsion fractures because the hamate of ulnar styloid process acts as a chisel chipping away a small dorsal fragment of the os triquetrum rather than ligaments or tendons tearing off a small piece of bone. 
injuries were acquired due to the same trauma mechanism, in two separate accidents, only $9 \mathrm{~h}$ apart of each other. To the best of our knowledge, this is the first case in which a simultaneous bilateral triquetral fracture is reported.

Contributors All authors contributed equally to the drafting and writing of the manuscript.

Competing interests None.

Patient consent Obtained.
Provenance and peer review Not commissioned; externally peer reviewed.

\section{REFERENCES}

1 Eiff MP, Hatch RL, Calmbach WL. Carpal fractures. In: Fracture management for primary care. 2nd edn. Philadelphia: Saunders, 2003.

2 Levy M, Fischel RE, Stern GM, et al. Chip fractures of the os triquetrum. J Bone Joint Surg 1979:61-B:355-7.

3 Höcker K, Menschik A. Chip fractures of the triquetrum. Mechanism, classification and results. J Hand Surg Br 1994;19B:584-8.

Copyright 2014 BMJ Publishing Group. All rights reserved. For permission to reuse any of this content visit

http://group.bmj.com/group/rights-licensing/permissions.

BMJ Case Report Fellows may re-use this article for personal use and teaching without any further permission.

Become a Fellow of BMJ Case Reports today and you can:

- Submit as many cases as you like

- Enjoy fast sympathetic peer review and rapid publication of accepted articles

- Access all the published articles

- Re-use any of the published material for personal use and teaching without further permission

For information on Institutional Fellowships contact consortiasales@bmjgroup.com

Visit casereports.bmj.com for more articles like this and to become a Fellow 